Gulawentah: Jurnal Studi Sosial

ISSN 2528-6293 (Print); ISSN 2528-6871 (Online)

Vol. 5, No. 1, Juni 2020, Hal 28-39

Tersedia online: http://e-journal.unipma.ac.id/index.php/gulawentah

\title{
Inisiatif dari Pesisir Utara Jawa: Merangkul Kearifan Lokal dan Kerjasama Antar Aktor Berkepentingan dalam Pemberdayaan Masyarakat Pesisir
}

\author{
Agnes Sunartiningsih dan Zita Wahyu Larasati* \\ Departemen Pembangunan Sosial dan Kesejahateraan, Fakultas Ilmu Sosial dan Ilmu Politik, \\ Universitas Gadjah Mada, Jl. Sosio Yustisa No. 2, Bulaksumur, Yogyakarta, Indonesia \\ Email: agnes_ugm@yahoo.co.id; *zita_wahyu@ugm.ac.id
}

Naskah diterima: 13/5/2020; Revisi: 25/5/2020; Disetujui: 30/5/2020

\begin{abstract}
Abstrak
Kemiskinan, ketimpangan pendapatan, dan kerusakan lingkungan merupakan masalah yang jamak ditemukan di wilayah pesisir utara Pulau Jawa. Kerusakan lingkungan sendiri merupakan dampak dari aktivitas masyakat pesisir dalam merespon sumber daya laut yang ada. Sekelompok masyakat yang berasal dari empat kelurahan di Kabupatan Jepara, Jawa Tengah menginisasi terbentuknya Kelompok Usaha Bersama (KUB) Berkah Samudra sebagai upaya warga lokal untuk mereduksi masalah tersebut. Pemberdayaan masyarakat pesisir oleh KUB Berkah Samudra dilakukan dengan mengoptimalkan kearifan lokal serta membangun kerjasama antara aktor kepentingan. Kerjasama tersebut dilakukan dengan mengandeng nelayan non anggota kelompok, entitias bisnis, akademisi, serta insitiusi pemerintah terkait. Hasil temuan dalam penelitian ini menunjukan bahwa basis kearifan lokal dan kerjasama antar aktor berkepentingan telah berhasil meningkatkan kesadaran ekologis serta kapasitas anggota maupun masyarakat luas dalam mengelola sumber daya lokal secara lebih bijak. Dengan demikian upaya pemberdayaan masyarakat yang dilakukan KUB Berkah Samudra telah berhasil meningkatkan kesejahteraan masyarakat pesisir utara Pulau Jawa secara umum.
\end{abstract}

Kata kunci: kearifan lokal; kerjasama antar aktor; inisiatif; pemberdayaan masayarakat pesisir

\section{Initiative from the North Coast of Java: Embracing Local Wisdom and Stakeholder Cooperation in Empowering Coastal Community}

\begin{abstract}
Poverty, income inequality, and destruction of the natural environment are common problems in the north coast of Java. The damage to the environment itself is the impact of the activities of coastal communities in response to existing marine resources. A group of people from four villages in Jepara Regency, Central Java, initiated the formation of the Berkah Samudra Joint Business Group as an effort by local residents to reduce the problem. The empowerment of coastal communities by KUB Berkah Samudra is carried out by optimizing local wisdom and building cooperation between interest actors. The collaboration is carried out by cooperating with non-group fishermen, business entities, academics, and related government institutions. The findings in this study indicate that the basis of local wisdom and cooperation between stakeholders has succeeded in increasing ecological awareness and the capacity of members and the wider community to manage local resources more wisely. Thus the community
\end{abstract}

DOI: 10.25273/gulawentah.v5i1.6617

Some rights reserved. 
empowerment efforts undertaken by KUB Berkah Samudra have succeeded in increasing the welfare of the north coast communities of Java in general.

Keywords: local wisdom; stakeholder cooperation; initiative; empowering coastal residents

\section{Pendahuluan}

Masyarakat pesisir merupakan sekumpulan manusia yang menggantungkan hidupnya di wilayah pesisir, sehingga pengelolaan bidang perikanan dan sejenisnya menjadi sektor penopang kehidupan masyarakat setempat (Fama, 2016). Dengan demikian tidak mengherankan jika sebagian besar masyarakat yang tinggal di daerah pesisir berprofesi sebagai nelayan. Profesi tersebut pun biasanya diturunkan turun-temurun dari generasi terdahulu kepada generasi saat ini. Ciri-ciri masyarakat pesisir selain tinggal di pinggir pesisir dan beprofesi sebagai nelayan juga ditandai dengan adanya interaksi sosial yang intensif antar masyarakatnya, dan proses mencari nafkah didasari oleh sifat gotong royong dan saling membantu (Fama, 2016)(Fama, 2016).

Dengan kelimpahan sumber daya alam yang berasal dari laut seperti kepiting, ikan, udang dan cumi-cumi ternyata tidak serta merta menyebabkan peningkatkan kualitas hidup masyarakat pesisir. Tingkat kemiskinan di daerah pesisir masih tergolong tinggi (Fama, 2016). Kerentanan akibat perubahan ekologis berpengaruh secara signifikan bagi kehidupan masyarakat pesisir, di mana terdapat hubungan tarik menarik antara aktivitas eksploitasi alam dengan upaya keberlangsungan hidup dari alam (Sofianto, 2017). Selain itu, terjadi masalah ekonomi seperti ketimpangan pendapatan. Kesenjangan pendapatan antara pelaku perikanan skala kecil dan skala besar mengakibatkan kemiskinan dialami nelayan kecil di pesisir utara Jawa (Ekosafitri et al., 2017). Hal ini diperparah dengan adanya overfishing dan perusakan terumbu karang yang menyebabkan menurunnya jumlah sumber daya alam di pesisir.

Dalam pengelolaan sumberdaya alam berbasis laut, masyarakat di wilayah pesisir masih melakukannya secara tradisional dan sederhana. Menurut (Wahyudin, 2003) ciri-ciri pengelolaan sumber daya alam secara tradisional seperti 1) pengelolaan sumber daya alam dilakukan secara berkelanjutan, 2) struktur pihak yang terlibat masih sangat sederhana, 3) bentuk pemanfaatanannya terbatas dalam skala kecil, 4) tipe masyarakat dan kegiatannya relatif homogen, 5) komponen pengelolaannya berasal dan berakar pada masyarakat, dan 6) rasa kepemilikan dan ketergantungan terhadap sumberdaya alam tinggi. Ditambahkan oleh (Ratmaya, 2013) aturan yang digunakan dalam pengelolaan sumber daya alam pada umumnya berakar dari permasalahan yang dihadapi untuk selanjutnya dirumuskan dalam bentuk kebijakan yang disepakati bersama sebagai aturan bersama. Peraturan tersebutlah yang kemudian menjadi tata cara masyarakat pesisir dalam mengelola sumber daya alam yang dimilikinya.

Bagi masyarakat pesisir isu mengenai pengelolaan sumber daya alam menjadi penting untuk diperhatikan, sebab seperti yang sudah disampaikan sebelumnya kehidupan masyarakat disokong oleh ketersediaan sumber daya alamnya. Menurut Waluyo dalam (Ekosafitri et al., 2017) setidaknya ada empat aspek yang dipertimbangkan dalam pemberdayaan wilayah pesisir seperti 1) keterpaduan wilayah secara ekologis, 2) keterpaduan antar sektor kesinambungan, 3) keterpaduan disiplin ilmu, dan 4) keterpaduan stakeholder baik pemerintah, pihak swasta/ investor, masyarakar pesisir, dan Lembaga Swadaya Masyarakat (LSM). Agar upaya pengelolaan melalui keterpaduan dapat berjalan dengan baik maka diperlukan kesinambungan dengan kapasitas sumber daya manusia dalam mengelola sumber daya alam tersebut. Sayangnya, sumber daya manusia masyarakat pesisir relatif rendah. Hal ini ditandai dengan rendahnya tingkat pendidikan masyarakat pesisir (Primyastanto et al., 2010).

Menurut (Sofianto, 2017) terdapat beberapa strategi yang dapat dilakukan untuk meningkatkan kapasitas sumber daya manusia wilayah pesisir seperti 1) memberikan pelatihan, pencerahan, dan keahlian sehingga masyarakat dapat berwirausaha, 2) memberikan penyuluhan teknologi yang tepat dalam bidangnya masing-masing serta melakukan pemberdayaan, 3) 
pemberdayaan kelompok masyarakat menjadi wadah kegiatan sosial ekonomi yang berkaitan dengan upaya peningkatkan kualitas hidup masyarakat pesisir, 4) pembukaan akses permodalan sehingga masyarakat mudah mengakses sektor perbankan, 5) transfer teknologi baru dalam pengembangan usahanya, 6) pembagian informasi terkait dengan pemasaran dengan melibatkan dinas terkait, 7) pemerintah memberikan fasilitas sarana dan prasarana yang dibutuhkan oleh pelaku usaha di wilayah pesisir, dan 8) adanya integrasi program antara pemerintah desa dengan kelompok pemberdayaan. Peningkatkan kapasitas sumber daya manusia berkaitan dengan kepemilikan dan pemanfaatan pengetahuan dan keterampilan sumber daya manusia dalam mengelola sumber daya yang dimilikinya. Peningkatan kapasitas tersebut dapat menjadi upaya untuk mengentaskan masalah terkait rendahnya kualitas sumber daya manusia di wilayah pesisir. Secara lebih lanjut, peningkatan kualitas sumber daya manusia dapat menjadi salah satu tolak ukur keberhasilan suatu program pemberdayaan masyarakat (Sunartiningsih, 2013).

Dalam kajian pemberdayaan masyarakat kesinambungan antara isu pengelolaan sumber daya alam beserta peningkatkan kapasitas sumber daya manusia dapat berjalan dengan beriringan melalui pengimplementasian beberapa prinsip pemberdayaan. Prinsip-prinsip yang dibutuhkan dalam program pemberdayaan masyarakat pesisir tersebut seperti berbasis pada kearifan lokal, dan bersandar pada nilai sosial, keterbukaan kejujuran, solidaritas, dan pelibatan masyarakat (Sofianto, 2017). Kearifan lokal sendiri secara lebih lanjut bertumbuh dan berkembang sejalan dengan dinamika pengetahuan masyarakat (Hanif, 2016). Hal ini diperkuat dengan hasil penelitian yang dilakukan Sunyoto menunjukan prinsip-prinsip lokal berpotensi menjadi sumber pembelajaran (Sunyoto, 2018). Dengan demikian kearifan lokal menjadi aspek penting dalam pelaksanaan pemberdayaan masyarakat.

Kelompok Usaha Bersama (KUB) Berkah Samudra merupakan salah satu kelompok usaha yang terletak di Kabupaten Jepara, Jawa Tengah. Kelompok ini diiniiasi oleh masyarakat pesisir yang berasal dari empat kelurahan yang berada di sekitar pinggir utara pantai Pulau Jawa. KUB Berkah Samudra sendiri beranggotakan 16 orang yang berprofesi sebagai nelayan bubu dan non nelayan. Nelayan bubu adalah istilah lokal merujuk kepada nelayan yang melakukan aktivitas penangkapan kepiting rajungan dengan menggunakan alat tradisional yang diberi nama $b u b u$. Sedangkan keikutsertaan anggota non nelayan dalam kegiatan kelompok ini didasari oleh kepemilikan pengetahuan dan keterampilan anggota tersebut berkaitan dengan pengelolaan sumber daya alam yang dibutuhkan oleh kelompok. Isu terkait dengan pengelolaan sumber daya alam menjadi dasar dibentuknya kelompok yang berdiri sejak tahun 2010 .

Sebelum adanya KUB Berkah Samudra, nelayan setempat mengalami penurunan jumlah hasil tangkapan ikan. Hal ini dikarenakan adanya overfishing yang dilakukan oleh nelayan setempat. Saat ini nelayan tidak melakukan pemilahan hasil tangkapan, misalkan saja kepiting rajungan yang sedang bertelur tidak dibiarkan menetaskan telurnya namun tetap ditangkap dan diperjualbelikan. Akibatnya tidak adanya proses reproduksi kepiting rajungan di daerah tersebut sehingga jumlahnya mengalami penurunan secara drastis. Hal ini diperparah dengan perusakan terumbu karang oleh nelayan yang menyebabkan makhluk hidup yang hidup di dasar laut kehilangan tempat untuk bereproduksi.

Sebagai upaya untuk mereduksi dampak negatif dari aktivitas yang dilakukannya, anggota KUB Berkah Samudra memanfaatkan kearifan lokal serta jejaring kemitraan untuk meningkatkan kesadaran ekologis di wilayahnya. Hal ini dilakukan dengan kegiatan restocking kepiting rajungan dan menjalin kerjasama dengan nelayan non anggota kelompok, perusahaan, dan pembeli kepiting rajungan. Kerjasama perusahaan telah membantu kelompok dalam upaya meningkatkan kapasitas sumberdaya manusianya melalui pelatihan dan pendampingan yang diberikan oleh akademisi dari perguruan tinggi setelah yang difasilitasi oleh perusahaan.

Penelitian ini bertujuan untuk mengeksplorasi inisiatif masyarakat pesisir utara Pulau Jawa melalui Kelompok Usaha Bersama (KUB) Berkah Samudra guna mereduksi masalah kemiskinan, ketimpangan pendapatan, dan ekologi yang terjadi di daerah pesisir. Dalam implementasi pemberdayaan masyarakat di daerah pesisir, KUB Berkah Samudra 
mendasarkannya pada kearifan lokal dan kerjasama antar stakeholder. Hal ini dilakukan untuk menjamin keberlanjutan program tanpa menegasikan pentingnya keseimbangan ekologis dan kepentingan ekonomi. Dilatarbelakangi oleh hal tersebut, maka penelitian ini mengangkat rumusan masalah mengenai bagaimana inisiatif warga pesisir utara Pulau Jawa dalam merajut kearifan lokal dan kerjasama antar stakeholder melalui program pemberdayaan masyarakat yang dilakukannya.

\section{Metode Penelitian}

Penelitian merupakan proses akademis yang dilakukan secara sistematik dengan tujuan untuk menngetahui sesuatu secara teliti, dan kritis dalam mencari fakta-fakta (Mulyadi, 2011). Metode yang digunakan dalam penelitian ini adalah metode penelitian kualitatif. Dengan menggunakan metode penelitian kualitatif, tim peneliti diberi kesempatan untuk melakukan eksplorasi secara mendalam guna menjawab rumusan masalah yang diangkat dalam penelitian ini (Mulyadi, 2011).

Metode pengumpulan data yang digunakan dalam penelitian ini adalah wawancara mendalam, diskusi kelompok terfokus, observasi dan pengumpulan data sekunder yang dilakukan sejak bulan Mei 2018 hingga Oktober 2019. Wawancara mendalam dilakukan oleh tim peneliti kepada semua anggota kelompok KUB Berkah Samudra pada bulan Mei dan November 2018 dilanjutkan pada bulan September 2019. Sedangkan sebagai upaya untuk memperkaya temuan lapangan, tim peneliti juga melakukan wawancara mendalam kepada pihak perusahaan dan masyarakat sekitar yang merasakan dampak dari adanya kegiatan KUB Berkah Samudra yang dilaksanakan pada bulan Mei dan November 2018 dilanjutkan dengan September dan Oktober 2019. Wawancara mendalam dilakukan secara beberapa kali untuk mengeksplorasi lebih mendalam informasi yang dibutuhkan oleh peneliti. Diskusi kelompok terfokus dilakukan untuk mengklarifikasi dan memperdalam temuan, serta dapat digunakan untuk mengukur kredibilitas data yang sudah didapatkan dari hasil wawancara mendalam (Afiyanti, 2008). Diskusi kelompok terfokus dilakukan dengan mengundang seluruh anggota KUB Berkah Samudra pada bulan Mei 2018.

Dari wawancara mendalam serta diskusi kelompok terfokus, peneliti menemukan bahwa kearifan lokal yang diproduksi oleh KUB Berkah Samudra berdasarkan atas pengalamannya berinteraksi serta beradaptasi dengan ekosistem lingkungan laut menjadi kekuatan dalam proses pemberdayaan masyarakat pesisir. Selain itu keterlibatan aktor berkepentingan lainnya memperkaya diskusi pemberdayaan masyarakat pesisir.

Observasi dilakukan tim peneliti selama penelitian ini berlangsung. Dalam proses observasi, selain melakukan pengamatan terhadap aktivitas yang dilakukan KUB Berkah Samudra peneliti juga menyambangi lokasi restocking kepiting rajungan dan Pulau Panjang. Sedangkan untuk pengumpulan data sekunder dilakukan peneliti dengan membaca dokumen milik KUB Berkah Samudra dan PT PLN Pembangkitan Tanjung Jati B Jepara terkait dengan aktivitas kelompok. Dari dokumentasi tersebut peneliti menemukan bahwa dalam kegiatan operasionalnya, KUB Berkah Samudra tidak hanya melibatkan anggota kelompok saja, namun juga melibatkan nelayan bubu non kelompok serta perusahaan, akademisi, dan dinas terkait. Pelibatan aktor lain tersebut memperkaya diskusi mengenai kerjasama antar aktor dalam pemberdayaan masyarakat pesisir.

Setelah data terkumpulkan, tim peneliti membaca ulang data yang sudah ada untuk kemudian dikoding berdasarkan kategori data yang dibutukan dalam peneliti ini. Data yang sudah terkompilasi tersebut kemudian dianalisis sesuai dengan perspektif yang digunakan dalam penelitian ini yaitu inisiatif masyarakat pesisir dalam proses pemberdayaan masyarakat melalui kearifan lokal dan kerjasama antar aktor berkepentingan. Setelah analisis selesai dilakukan oleh tim peneliti selanjutnya data disajikan dalam bentuk deskripsi dan gambar. 


\section{Hasil dan Pembahasan}

\section{Faktor Pemberdayaan Nelayan Kepiting Rajungan di Pesisir Utara Pulau Jawa}

Kehidupan masyarakat pesisir tidak dapat dilepaskan dari sektor perikanan dan sejenisnya. Masyarakat pesisir senantiasa hidup beradaptasi dengan lingkungan fisik laut. Hal ini dikarenakan perikanan merupakan sektor penopang ekonomi, sosial, dan budaya masyarakat pesisir. Corak ekonomi masyarakat pesisir tidak berbeda jauh dengan ekonomi masyarakat agraris khususnya petani kecil yang tergantung pada penggunaan teknologi tradisional. Hal ini tentu saja memengaruhi kemampuan masyarakat pesisir dalam menghasilkan keuntungan dari aktivitas ekonomi yang dilakukannya.

Di pesisir pantai Pulau Jawa, terdapat beberapa nelayan $b u b u$ yang tergabung dalam Kelompok Usaha Bersama (KUB) Berkah Samudra. Nelayan bubu merupakan istilah lokal merujuk kepada nelayan yang melakukan aktivitas budidaya kepiting rajungan dengan menggunakan alat tradisional yang disebut bubu. Anggota dari KUB Berkah Samudra berasal dari empat kelurahan setempat. Dalam kegiatan operasionalnya, tidak semua anggota KUB Berkah Samudra merupakan nelayan kepiting rajungan. Beberapa di antaranya merupakan anggota non nelayan yang memberikan sumbangsihnya berupa tenaga dan pikiran. Sumbangsih tersebut bertujuan untuk meningkatkan kesejahteraan nelayan dan mengembangkan usaha kelompok melalui Restocking rajungan.

Secara umum Restocking rajungan adalah upaya alternatif dalam memenuhi ketersediaan kepiting rajungan dalam jangka panjang tanpa menyebabkan penurunan jumlah kepiting rajungan di laut bebas. Pada tahap awal, kegiatan ini dilakukan dengan cara mencari kepiting rajungan untuk kemudian dipilah berdasarkan kondisi kepiting. Kepiting yang sedang dalam proses pembuahan akan ditempatkan ada krebox; sebuah wadah untuk mengarantina kepiting rajungan yang sedang bertelur sebelum kepiting rajungan tersebut melepaskan telur-telurnya. Ciri-ciri dari induk kepiting rajungan yang siap melepaskan telurnya ditandai dengan warna telur kepiting rajungan yang mulai menghitam. Setelah telur kepiting rajungan menetas, maka anak kepiting tersebut akan dilepaskan di laut bebas. Sedangkan kepiting rajungan yang tidak dalam kondisi bertelur akan ditangkap oleh nelayan bubu.

Pendirian KUB Berkah Samudra diinisiasi oleh ketua kelompok. Dalam aktivitasnya, peningkatan kapasitas anggota seperti pengetahuan dan keterampilan dalam budidaya kepiting rajungan dilakukan secara mandiri. Seperti peningkatkan pengetahuan dan keterampilan budidaya kepiting rajungan melalui restocking kepiting rajungan. Pengetahuan dan keterampilan tersebut merupakan hasil dari uji coba secara tradisional yang dilakukan oleh KUB Berkah Samudra. Uji coba tersebut dilakukan berdasarkan pengalaman anggota kelompok yang berprofesi sebagai nelayan bubu. Hasil dari uji coba tersebut terlembagakan menjadi pengetahuan lokal yang berguna untuk menjaga ketersediaan kepiting rajungan secara arif.

Kegiatan restocking kepiting rajungan sendiri dilatarbelakangi oleh adanya permasalahan terkait dengan penurunan jumlah kepiting rajungan di laut lepas. Banyak nelayan $b u b u$ yang menangkap kepiting rajungan tanpa memperhatikan kondisi dari kepiting rajungan hasil tangkapannya tersebut. Alhasil kepiting rajungan yang sedang bertelur ditangkap oleh nelayan tanpa sempat melepaskan telur-telurnya ke laut lepas. Hal ini menyebabkan jumlah kepiting rajungan di laut lepas menjadi berkurang secara drastis. Dengan melakukan pelepasan anak kepiting rajungan ke laut lepas, pada dasarnya KUB Berkah Samudra sedang berupaya untuk menjaga stabilitas perekonomian di daerah tersebut. Hal ini dikarenakan kepiting rjaungan merupakan komoditas utama dari penduduk setempat, di mana secara nasional hasil kepiting rajungan di daerah tersebut menjadi komoditas ekspor nomor 2 setelah ikan tuna. Untuk itu kepiting rajungan merupakan potensi ekonomi yang semestinya dikelola secara arif.

Restocking kepiting rajungan yang telah dilakukan oleh KUB Berkah Samudra memiliki fungsi penting untuk menjaga stabilitas perekonomian di daerah pesisir tersebut. Kepiting rajungan yang sudah ditangkap oleh anggota KUB Berkah Samudra setelah diolah melalui 
proses perebusan kemudian dibeli oleh pabrik dengan harga sekitar Rp 100.000/ kg. Dengan terjaganya jumlah kepiting rajungan melalui restocking kepiting rajungan, maka aktivitas ekonomi berbasis pada transaksi jual beli kepiting rajungan dapat berjalan dengan baik. Bagi kelompok, kegiatan ini merupakan wujud aktualisasi diri sebagai nelayan yang menjadikan kepiting rajungan sebagai komoditas sekaligus sebagai nelayan yang berupaya untuk menjaga keseimbangan ekosistemnya. Dengan demikian aktivitas ekonominya tidak hanya mampu untuk memenuhi kebutuhan ekonominya namun juga menjadi penghidupan di masa mendatang dan keseimbangan ekologi.

Selain itu, kegiatan restocking kepiting rajungan juga telah mengatasi keterbatasan akses terhadap sumber daya laut. Nelayan tradisional yang hanya memiliki perahu kecil sulit untuk berlayar jauh ke tengah samudra untuk menangkap ikan, karenannya mereka hanya berlayar di pesisir laut. Ketersediaan kepiting rajungan yang melimpah memudahkan nelayan untuk mendapatkan hasil laut tanpa harus menyebrang hingga ke tengah samudra. Dari sinilah memunculkan kesadaran akan pentingnya menjadi keseimbangan ekosistem laut melalui budidaya restocking kepiting rajungan. Upaya tersebut merupakan upaya adaptasi dari nelayan bubu dalam merespon ekosistem lautnya.

\section{Mekanisme Keterlibatan Nelayan Bubu Non Anggota KUB D Berkah Samudra}

KUB Berkah Samudra merupakan satu-satunya kelompok nelayan yang secara aktif terlibat dalam upaya pelestarian lingkungan. Di samping melakukan restocking kepiting rajungan, KUB Berkah Samudra juga melakukan konservasi terumbu karang dengan mebuat Terumbu Karang Buatan (TKB). KUB Berkah Samudra sudah berdiri sejak tahun 2010 dalam dinamika keanggotannya, jumlah anggota KUB Berkah Samudra mengalami fluktuasi hingga saat ini jumlah anggota tetap KUB Berkah Samudra ialah 15 orang. Secara umum pengetahuan dan keterampilan terkait dengan restocking kepiting rajungan masih relatif baru dimiliki oleh masyarakat pesisir di daerah tersebut.

Dalam aktivtiasnya, anggota KUB Berkah Samudra secara sukarela menyediakan stok kepiting rajungan melalui kegiatan pelepasan anak kepiting rajungan ke laut lepas. Kesukarelaan tersebut dilakukan tanpa khawatir bahwa anak kepiting rajungan yang dilepaskannya berpotensi ditangkap oleh nelayan lainya ketika sudah dewasa. Hal ini selain dikarenakan adanya pertimbangan ekologis terkait dengan jumlah kepiting rajungan di laut bebas juga dikarenakan setiap kepiting rajungan yang sedang bertelur dapat melepaskan 100 telur dalam satu kali proses pembuahannya.

Sebagai bentuk dukungan kepada nelayan bubu di luar anggota kelompok, salah satu anggota KUB Berkah Samudra menyediakan saung yang didirikan di atas laut sebagai tempat persinggahan bagi nelayan bubu non anggota KUB Berkah Samudra. Akibat dari disediakannya fasilitas tersebut telah menciptakan interaksi antara nelayan bubu non KUB Berkah Samudra dengan nelayan bubu KUB Berkah Samudra. Interaksi yang terbentuk tersebut secara langsung telah berdampak bagi upaya konservasi yang dilakukan KUB Berkah Samudra. Hal ini ditandai dengan keikutsertaan nelayan bubu non kelompok dengan menyerahkan hasil kepiting rajungan bertelur yang ditangkapnnya kepada KUB Berkah Samudra untuk dikarantina dalam krebox untuk selanjutnya dilepaskan ke laut bebas ketika telur kepiting rajungan telah menetas.

Keterlibatan nelayan bubu non anggota KUB dalam kegiatan restocking kepiting rajungan KUB Berkah Samudra menandakan bahwa pengembangan pengetahuan dan keterampilan tidak hanya dirasakan oleh anggota kelompok saja. Peningkatan kapasitas dan kesadaran atas pentingnya keseimbangan ekologi laut juga memberi dampak bagi nelayan bubu non anggota kelompok.

\section{Dukungan Berbagai Aktor bagi KUB Berkah Samudra}


Dalam pelaksanaan tanggung jawab sosial dan lingkungan oleh perusahaan, Pemerintah Indonesia mengaturnya melalui UU No. 40 tahun 2007 pasal 74 tentang perseroan terbatas (UU PT) dan UU No. 25 tahun 2007 pasal 15(b) dan pasal 16(d) tentang penanaman modal (UU PM). Oleh karenanya bisnis bukan hanya sekadar memiliki tanggung jawab untuk memperoleh keuntungan ekonomis namun juga berkontribusi bagi kelestarian lingkungan dan juga kesejahteraan masyarakat di sekitarnya.

PT PLN Pembangkitan Tanjung Jati B Jepara, merupakan salah satu perusahaan pengelola pembangkit listrik tenaga uap yang berlokasi di pesisir utara Pulau Jawa. Sebagai perwujudan komitmen tanggung jawab sosial perusahaan, PT Pembangkitan Tanjung Jati B Jepara melakukan serangkaian program pemberdayaan masyarakat, salah satunya melalui Program Pengembangan Ekowisata Pulau Panjang. Dalam program Pengembangan Ekowisata Pulau Panjang, perusahaan memfokuskannya pada dua (2) aspek yaitu aspek lingkungan dan aspek sosial-ekonomi. Penekanan pada aspek lingkungan dilatarbelakangi oleh keprihatinan perusahaan atas kerusakan ekosistem laut di sekitar Pulau Panjang akibat aktivtias nelayan yang kurang ramah lingkungan. Sebelum adanya kegiatan yang diinsiasi oleh KUB Berkah Samudra, nelayan $b u b u$ di wilayah setempat melakukan penangkapan kepiting rajungan tanpa memperhatikan kondisi kepiting tersebut. Kepiting yang sedang bertelur tidak dibiarkan menetaskan telunya sebagai upaya untuk menjaga jumlah kepiting rajungan di laut. Akibatnya nelayan $b u b u$ mengalami kesulitan untuk menangkap kepiting rajungan. Ekosistem laut Pulau Panjang merupakan salah satu ekosistem terlengkap di pesisir Pantai Utara Jawa.

Oleh karena itu, perusahaan mengawali program ini dengan beragam kegiatan lingkungan seperti penanaman lamun, penenggelaman APR yang ditanami terumbu karang buatan, aksi bersih pantai coastal clean up dan penanaman cemara laut. Kegiatan-kegiatan ini bukan hanya melibatkan KUB Berkah Samudra namun juga menyertakan masyarakat sekitar yang memanfaatkan Pulau Panjang seperti PKL.

Selain memiliki tujuan konservasi, perusahaan juga menangkap potensi lain dari Pulau Panjang yakni sebagai destinasi wisata edukasi. Pengembangan wisata ini dipandang dapat memberikan nilai lebih dari program Pengembangan Ekowisata Pulau Panjang agar tidak sekedar memberikan manfaat bagi aspek lingkungan namun juga sosial-ekonomi bagi masyarakat. Hal ini kemudian dibahas bersama dengan aktor berkepentingan terkait melalui forum group discussion ( $f g d$ ). FGD tersebut dilaksankan pada akhir tahun 2016.

Selain itu, sebagai upaya untuk meningkatkan kapasitas dari masyarakat guna mendukung Pengembangan Ekowisata Pulau Panjang, perusahaan menyelenggarakan beberapa pelatihan. Pelatihan yang diberikan seperti pelatihan restocking kepiting rajungan dan pelatihan menyelam. Pelatihan restocking rajungan dilakukan sebagai upaya untuk melestarikan populasi rajungan yang ada. Dengan stabilnya populasi kepiting rajungan yang ada di lautan maka memudahkan nelayan dalam menangkap kepiting rajungan sehingga berdampak pada peningkatkan pendapatan nelayan.

Pada kegiatan restocking rajungan, perusahaan tidak hanya memberikan pelatihan namun juga memberikan bantuan berupa krebox (tempat untuk mengkarantina rajungan yang sedang bertelur) dan juga uang sebesar RP.1.000.000,00. Uang tunai tersebut diperuntukan untuk membantu KUB Berkah Samudra sebagai penerima program untuk membeli rajungan yang sedang bertelur dari nelayan agar tidak dijual terlebih dahulu sebelum telurnya lepas kembali ke lautan.

Peran perusahaan dalam kegiatan restocking rajungan ini sangat membantu para nelayan sekaligus menjadi investasi sosial bagi perusahaan. Konsep investasi sosial adalah sebagai investasi pada sumber daya manusia maupun kelompok untuk dapat memajukan kesejahteraan agar setiap individu berkontribusi bagi penciptaan kesejahteraan. Investasi sosial dalam restocking rajungan ini terutama diarahkan pada program peningkatan keterampilan dan pemberdayaan komunitas dan peningkatan kapasitas kelompok. Tujuan dari investasi sosial 
adalah kesejahteraan masyarakat nelayan dalam jangka panjang dengan ketersediaan rajungan disekitar mereka.

Peran akademisi dalam mendukung kegiatan restocking kepiting rajungan KUB Berkah Samudra tidak terlepas dari intervensi yang dilakukan PT PLN Pembangkitan Tanjung Jati B Jepara dalam kegiatan operasional KUB Berkah Samudra. PT PLN Pembangkitan Tanjung Jati B Jepara membangun kerjasama dengan salah satu perguruan tinggi di Jawa Tengah guna memberikan dampingan dan pelatihan bagi anggota KUB Berkah Samudra. Setidaknya terdapat dua fokus pendampingan dan pelatihan yang diberikan akademisi bagi KUB Berkah Samudra yaitu pengembangan konservasi terumbu karang dan konservasi lamun. Beberapa pelatihan yang dilakukan seperti pelatihan selam dasar dan pelatihan restocking kepiting rajungan. Pelatihan selam dasar merupakan bentuk pengembangan aktivitas yang dilakukan KUB Berkah Samudra dalam upaya untuk meningkatkan kapasitas anggota KUB Berkah Samudra dalam merawat konservasi terumbu karang yang dilakukannya. Dalam pelatihan tersebut peserta pelatihan akan mendapatkan sertifikat sehingga kegiatan penyelaman yang dilakukan oleh anggota kelompok dianggap legal secara hukum. Selain itu dengan adanya sertifikat tersebut dapat digunakan oleh anggota kelompok untuk mengembangkan usaha baru berupa pendampingan penyelaman. Sedangkan peran pemerintah ditandai dengan kehadiran dinas pariwisata dalam perumusan rencana Pengembangan Ekowisata Pulau Panjang dan kegiatan konservasi yang dilakukan oleh KUB Berkah Samudra.

\section{Kearifan Lokal dan Peran Aktor Berkepentingan dalam Pemberdayaan Proses Pemberdayaan}

Kearifan lokal muncul saat kesadaran ekologis terkait dengan pentingnya menjaga keseimbangan jumlah kepiting rajungan di laut lepas bertemu dengan kesadaran sosial ekonomi terkait dengan upaya pemenuhan kebutuhan hidup. Menurut (Nawastuti, 2018) kearifan lokal masyarakat pesisir dihasilkan dari sekumpuplan pengalaman yang diintegrasikan dengan budaya dan kondisi alam setempat. Kearifan lokal tersebut merupakan bentuk refleksi anggota KUB Berkah Samudra atas pengalamannya yang diimplementasikan melalui kegiatan restocking kepiting rajungan. Kegiatan tersebut dilakukan dengan meminimalisir kerusakan lingkungan.

Selain melakukan kegiatan restocking kepiting rajungan, dengan kearifan lokal yang dimilikinya KUB Berkah Samudra juga menyerukan kepada anggotanya untuk tetap mempertahakankan penggunaan alat tangkap tradisional dalam kegiatan penangkapan kepiting rajungan. Penggunaan alat tangkap tradisional tidak memberikan dampak negatif kepada ekosistem laut sebab dilakukan tanpa menggunakan bahan kimia. Selain itu dalam upaya penangkaran kepiting rajungan, pun wadah berupa krebox pun tidak mengandung bahan kimia yang berbahaya bagi lingkungan laut.

Kearifan lokal yang dimiliki oleh KUB Berkah Samudra juga disebarluaskan kepada anggota non KUB Berkah Samudra. Hal ini dilakukan agar semakin banyak jumlah nelayan bubu yang memiliki kesadaran ekologis. Melalui pembelian kepiting rajungan dari nelayan non KUB Berkah Samudra, secara tidak langsung nelayan bubu non anggota kelompok tersebut telah berkontribusi dalam kegiatan restocking kepiting rajungan. Hal ini dilakukan melalui penyerahan kepiting rajungan yang sedang bertelur kepada KUB Berkah Samudra untuk dikarantina di dalam krebox. Transaksi ekonomi ini telah berkrontribusi bagi peningkatkan kesadaran ekologis nelayan bubu non anggota kelompok yang berbasis pada kearifan lokal.

Dari keterlibatan nelayan anggota dan non anggota KUB Berkah Samudra inilah kemudian memunculkan solidaritas antar nelayan dalam upaya untuk menjaga keseimbangan ekosistem laut. Nelayan-nelayan tersebut saat ini mendasarkan aktivitas ekonominya pada kearifan lokal yang berbasis pada kesimbangan ekosistem. Hal ini dikarenakan dampak dari adanya kesadaran ekologis yang terimplementasikan dalam kegiatan restocking kepiting rajungan sudah dirasakan sendiri oleh mereka. Dengan kegiatan restocking kepiting rajungan, 
nelayan anggota maupun non anggota KUB Berkah Samudra tidak khawatir terkait dengan penurunan jumlah kepiting rajungan di laut lepas mereka. Sebab jumlah kepiting rajungan dapat terjaga dengan penangkaran kepiting rajungan petelur melalui kegiatan restocking kepiting rajungan. Bahkan dari kegiatan restocking tersebut nelayan bubu di daerah terseut mengalami peningkatan hasil tangkapan.

Kegiatan restocking kepiting rajungan yang diinisasi oleh KUB Berkah Samudra sendiri terhitung masih baru. KUB Berkah Samudra melakukan kegiatan restocking kepiting rajungan ini berdasarkan atas pengalamannya berinteraksi dengan laut dan bentuk adaptasi mereka terhadap kehidupan laut. Refleksi tersebut dilakukan secara mandiri oleh anggota kelompok. Dalam konteks ini, maka pengondisian proses belajar bersama dilakukan didasari oleh kesadaran diri anggota atas pentingnya keseimbangan lingkungan. Proses belajar bersama yang dilakukan KUB Berkah Samudra berhasil memproduksi pengetahuan kolektif yang termanifestasikan dalam kegiatan restocking kepiting rajungan berbasis kearifan lokal. Hasil belajar bersama tersebut kemudian dibagikan kepada nelayan bubu non anggota kelompok melalui pendekatan kultural sehingga proses transfer knowledge bisa berlangsung secara efektif. Proses transfer knowledge merupakan salah satu poin penting yang harus diperhatikan, karena dari sinilah munculnya pengetahuan, kesadaran, kemauan, kemampuan dan nilai - nilai luhur lainnya dapat dikembangkan.

Sebagai proses belajar bersama kegiatan restocking kepiting rajungan telah meningkatkan pengetahuan dan keterampilan nelayan $b u b u$. Setiap anggota yang dalam hasil tangkapannya terdapat kepiting rajungan yang sedang bertelur secara sadar akan langsung meletakan kepiting rajungan petelur tersebut di dalam krebox yang sudah disediakan kelompok yang mendapatkan rajungan bertelur akan langsung meletakkan rajungan tersebut. Kegiatan ini memberikan nilai tambah bagi anggota kelompok maupun nelayan rajungan bubu pada umumnya karena kegiatan restocking membantu menyediakan stok rajungan di laut dan di daerah sekitar penebaran telurtelur rajungan tersebut.

Dalam upaya untuk menjaga kelestarian lingkungan melalui kegiatan restocking kepiting rajungan dan konservasi terumbu karang, KUB Berkah Samudra menjalin kerjasama dengan pihak lain seperti perusahaan PT PLN Pembangkitan Tanjung Jati B Jepara. Kerjasama ini didasari oleh kesamaan visi misi antara KUB Berkah Samudra dengan PT PLN Pembangkitan Tanjung Jati B Jepara.. Sebagai bentuk dukungan terhadap upaya pelestarian lingkungan yang dilakukan oleh KUB Berkah Samudra, PT PLN Pembangkitan Tanjung Jati B Jepara. menyediakan tenaga pendamping berpengalaman yang berasal dari kalangan akademis. Tenaga pendamping berpengalaman tersebut memberikan pelatihan serta pendampingan bagi KUB Berkah Samudra sebagai upaya untuk meningkatkan kapasitas anggota KUB Berkah Samudra.

Selain itu, PT PLN Pembangkitan Tanjung Jati B Jepara. juga menggandeng pemerintah melalui Dinas Pariwisata setempat agar memberikan izinnya untuk warga setempat bersama dengan KUB Berkah Samudra dan PT PLN Pembangkitan Tanjung Jati B Jepara. mengembangkan daerah pesisir tersebut sebagai tujuan destinasi wisata. Dampak dari adanya kerjasama lintas sektor ini ialah peningkatkan pengetahuan dan keterampilan anggota KUB Berkah Samudra serta peningkatan pentingnya menjaga keseimbangan ekosistem laut. Hal ini diperlukan mengingat kerjasama antara aktor diperlukan untuk memastikan pengelolaan sumber daya alam berkelanjutan dapat tercapai.

Dalam aktivitas ekonominya KUB Berkah Samudra juga telah bekerjasama dengan pembeli kepiting rajungan. Nelayan anggota kelompok maupun non anggota kelompok yang terlibat dalam kegiatan restocking kepiting rajungan dapat memanfaatkan jaringan perdagangan kepiting rajungan KUB Berkah Samudra melalui penjualan hasil tangkapan kepada KUB Berkah Samudra. Bagi anggota kelompok hal ini bersifat wajib, sehingga dapat memudahkan anggota kelompok dalam mendapatkan keuntungan dari aktivitas perdagangan kepiting rajungannya. Syarat penjualan hasil tangkapan kepiting rajungan di KUB Berkah Samudra adalah kepiting rajungan berukuran besar dan sedang tidak bertelur. 
Kepiting rajungan yang sedang bertelur atau masih kecil akan dimasukan dalam wadah karantina sebelum telurnya yang sudah menetas dilepas ke laut dan kepiting rajungan dewasa tersebut.

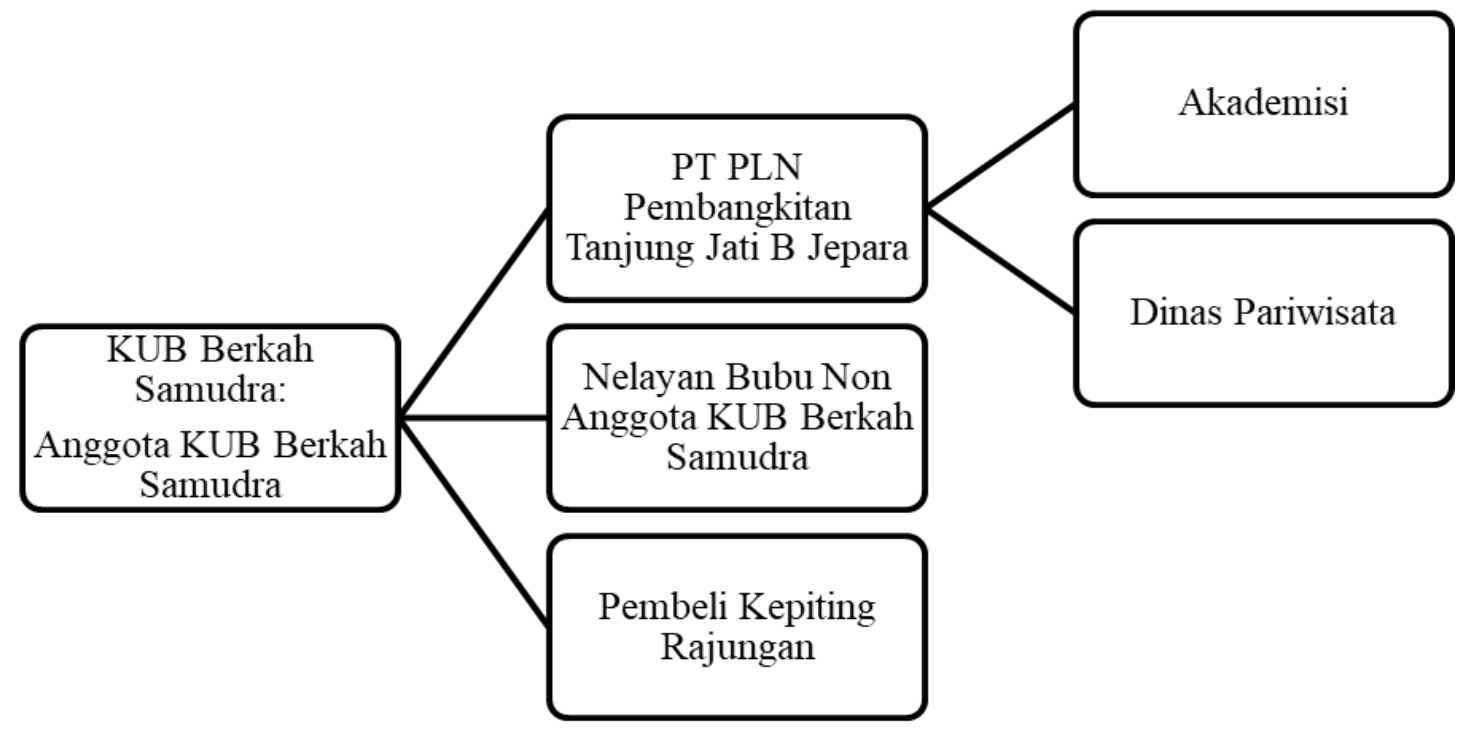

Gambar 1. Bagan aktor-aktor yang bekerjasama dengan KUB Berkah Samudera Sumber: Diolah dari hasil penelitian lapangan, 2019

Kesadaran ekologis yang dibangun oleh KUB Berkah Samudra telah berkontribusi bagi peningkatkan kesadaran mengenai keseimbangan lingkungan bagi aktor yang terlibat di dalamnya. Hal ini khususnya dikarenakan adanya kegiatan restocking kepiting rajungan guna meminimalisir adanya overfishing terhadap kepiting rajungan. Kegiatan restocking kepiting rajungan menjadi simbol kearifan lokal bahwa untuk menjaga keseimbangan ekosistem melalui pembatasan jenis kepiting rajungan yang dapat diperjualbelikan dan pengarantinaan kepiting rajungan yang sedang bertelur. Hal ini ternyata efektif dilakukan sebab dampak dari adanya restocking kepiting rajungan dapat dirasakan secara langsung oleh nelayan bubu anggota KUB Berkah Samudra maupun non anggota KUB Berkah Samudra melalui peningkatan pendapatan akibat kemudahan dalam menangkap kepiting di daerah pinggiran laut.

\section{Simpulan}

Dalam upaya untuk menekan angka kemiskinan dan ketimpangan pendapatan serta kerusakan ekosistem laut akibat aktivitas ekonomi yang dilakukan oleh nelayan, sekelompok masyarakat pesisir utara Pulau Jawa yang berasal dari empat kelurahan di Kabupaten Jepara menginisasi berdirinya Kelompok Usaha Bersama (KUB) Berkah Samudra. Kegiatan KUB Berkah Samudra berfokus pada isu manajemen pengelolaan sumber daya di pesisir utara Pulau Jawa dimana implementasi kegiatan tersebut berbasis pada kearifan lokal dan kerjasama antar aktor berkepentingan. Kearifan lokal dimanfaatkan oleh KUB Berkah Samudra untuk meningkatkan kesadaran ekologis masyarakat pesisir, khususya nelayan dalam memanfaatkan sumber daya yang berasal dari laut. Implementasi kearifan lokal dilakukan melalui kegiatan restocking kepiting rajungan. Sebelum ada kegiatan tersebut, nelayan kepiting rajungan tidak memperhatikan dampak negatif dari aktivitasnya di laut. Hal ini ditandai dengan tidak adanya pemilahan antara kepiting rajungan biasa dengan kepiting rajungan yang sedang bertelur. Dampak dari nihilnya pemilahan tersebut menyebabkan penurunan jumlah kepiting rajungan. Melalui kegiatan restocking, telah memanfaatkan kearifan lokal yang bersumber dari refleksi 
pengalamannya sebagai nelayan kepiting rajungan dengan teknologi sederhana yang mereka kuasai. Hasil dari pemanfaatan kearifan lokal dalam kegiatan pemberdayaan yang dilakukan oleh KUB Berkah Samudra ialah peningkatan kesadaran ekologis serta kapasitas dari nelayan kepiting rajungan setempat.

Selain itu, kegiatan restocking kepiting rajungan yang dilakukan oleh KUB Berkah Samudra tidak hanya melibatkan masyarakat pesisir yang menjadi anggotanya, nelayan non anggota KUB Berkah Samudra, sektor swasta yang diwakili oleh PT PLN Pembangkitan Tanjung Jati B Jepara, akademisi serta pemerintah daerah melalui Dinas Pariwisata setempat turut berpartisipasi dalam kegiatan KUB Berkah Samudra. Hal ini semakin memperluas jangkauan kelompok guna meningkatkan kesadaran ekologis serta kapasitas dalam budidaya kepiting rajungan. Dengan demikian upaya pemberdayaan masyarakat yang dilakukan KUB Berkah Samudra juga berhasil meningkatkan kesejahteraan masyarakat pesisir secara umum.

\section{Ucapan Terimakasih}

Terima kasih kepada Departemen Pembangunan Sosial dan Kesejahteraan, Fisipol, UGM dan SODEC (Social Development Center), Departemen Pembangunan Sosial dan Kesejahterana, Fisipol, UGM atas dukungannya dalam penelitian yang dilaksanakan oleh tim peneliti

\section{Daftar Pustaka}

Afiyanti, Y. (2008). Validitas dan Reliabilitas dalam Penelitian Kualitatif. Jurnal Keperawatan Indonesia, 12(2), 137-141. https://doi.org/https://doi.org/10.7454/jki.v12i2.212

Ekosafitri, K. H., Rustiadi, E., \& Yulianda, F. (2017). Pengembangan Wilayah Pesisir Pantai Utara Jawa Tengah Berdasarkan Infrastruktur Daerah: Studi Kasus Kabupaten Jepara. Journal of Regional and Rural Development Planning, 1(2), 145-157. https://doi.org/https://doi.org/10.29244/jp2wd.2017.1.2.145-157

Fama, A. (2016). Komunitas Masyarakat Pesisir Di Tambak Lorok, Semarang. Komunitas Masyarakat Pesisir Di Tambak Lorok, Semarang, 11(2), 65-75. https://doi.org/10.14710/sabda.v11i2.16047

Hanif, M. (2016). Local Wisdom of the Community in Handling Mental Retardation People ( A Case Study of "Kampung Idiot" in Sidoharjo Village, Jambon District, Ponorogo Regency). Sodality: Jurnal Sosiologi Pedesaan, 4(3), 242-248. https://doi.org/10.22500/sodality.v4i3.14433

Mulyadi, M. (2011). Penelitian Kuantitatif dan Kualitatif Serta Pemikiran Dasar Menggabungkannya. Jurnal Studi Komunikasi Dan Media, 15(1), 128-137.

Nawastuti, D. (2018). Kearifan Lokal Masyarakat Pesisir dalam Memahami Teknologi Hasil Perikanan. Jurnal Maksipreneur: Manajemen, Koperasi, Dan Entrepreneurship, 8(1), 3244. https://doi.org/http://dx.doi.org/10.30588/jmp.v8i1.374

Primyastanto, M., Dewi, R. P., \& Susilo, E. (2010). Perilaku Perusakan Lingkungan Masyarakat Pesisir Dalam Perspektif Islam Environment Destruction Behavior of The Coastal People in Islamic Perspective. Jurnal Pembangunan Dan Alam Lestari, 1(1), 1-11.

Ratmaya, W. (2013). Seke dan Ikan Malalugis di Desa Bebalang, Kabupaten Kepulauan Sangihe, Sulawesi Utara. Sabda: Jurnal Kajian Kebudayaan, 8(1), 91-97. https://doi.org/https://doi.org/10.14710/sabda.8.1.91-97

Sofianto, A. (2017). Prinsip-prinsip Penanggulangan Kemiskinan di Wilayah Pesisir Utara Jawa Tengah. Buletin Ilmiah Marina Sosial Ekonomi Kelautan Dan Perikanan, 2(2), 81-91. https://doi.org/http://dx.doi.org/10.15578/marina.v2i2.4679 
Sunartiningsih, A. (2013). Merajut Kesejahteraan di Aras Lokal (L. Z. E. Astuti (ed.); pp. 4355). Azzagrafika.

Sunyoto, S. (2018). Tradisi Bersih Kali (Studi Kearifan Lokal dan Potensinya sebagai Sumber Pembelajaran IPS SD). Gulawentah:Jurnal Studi Sosial, 3(2), 79-89. https://doi.org/10.25273/GULAWENTAH.V3I2.3164

Wahyudin, Y. (2003). Sistem Sosial Ekonomi dan Budaya Masyarakat Pesisir. Makalah Disampaikan Pada Pelatihan Pengelolaan Kawasan Konservasi Perairan, Tanggal, 5. 